\title{
Triglyceride Glearing in Glycogen Storage Disease
}

\author{
P. P. Forget, ${ }^{[17]}$ J. Fernandes, and P. Haverkamp Begemann \\ Department of Pediatrics, Sophia Children's Hospital and Neonatal Unit, Medical School, \\ Erasmus University, Rotterdam, The Netherlands
}

\begin{abstract}
Extract
Peripheral uptake of triglyceride from plasma was investigated by intravenous fat tolerance tests and by postheparin lipoprotein lipase measurements in children with different types of glycogen storage disease.

The patients with a glucose 6-phosphatase deficiency were characterized by a [significantly diminished triglyceride elimination rate $(5.79 \pm 2.78 \% / \mathrm{min})$ and 5 -min postheparin lipoprotein lipase activity $(40.2 \pm 23 \mu \mathrm{Eq}$ fatty acid (FA)/liter/ $\mathrm{min})$. The patients with a deficiency of debranching enzyme showed a significantly diminished triglyceride elimination rate $(4.84 \pm 1.61 \% / \mathrm{min})$ whereas the 5 -min postheparin lipoprotein lipase activities did not significantly differ from the control values $(49.6 \pm 27.7 \mu \mathrm{Eq} \mathrm{FA} /$ liter $/ \mathrm{min})$.

The patients with a deficiency of the phosphorylase system showed neither a significantly diminished triglyceride elimination rate $(7.34 \pm 2.65 \% / \mathrm{min})$ nor a diminished 5-min postheparin lipoprotein lipase activity $(61.7 \pm 30.1 \mu \mathrm{Eq} \mathrm{FA} /$ liter/ $\min$ ).

Triglyceride elimination rates were correlated positively lipase activities $(\mathrm{r}=0.55, P<0.05)$.

\section{Speculation}

The dietary treatment of hyperlipidemia in hepatic glycogenosis might be based on the outcome of the intravenous fat tolerance test, a low fat clearance being an indication for a low fat, high carbohydrate diet, a normal fat tolerance for a high fat, low carbohydrate diet.
\end{abstract}

\section{Introduction}

Little is known about the causes of hyperlipidemia in patients with glycogen storage disease (GSD) $[4,5,8]$.

The highest lipid levels are found in patients with a glucose 6-phosphatase deficiency. They have the highest fatty acid cholesterol ratios and sometimes even a pre- $\beta$-band on the electropheretograms. De novo fatty acid synthetizing activity from citrate is high in liver biopsies of these patients [7]. The pathogenesis of the hypertriglyceridemia in patients with a glucose 6-phosphatase deficiency is presumed to be as follows: in the fasting state, conversion of glucose 6-phosphate to glucose is blocked, so that glycogen can only be degraded to pyruvate through the glycolytic pathway. Part of the excess pyruvate is converted into lactate, another part into acetyl-CoA, and thence into fatty acids, predominantly palmitate $[4,12]$.

Hyperlipidemia is less striking in children with a deficiency of debranching enzyme or of the phosphorylase system. In the latter deficiencies, the hyperlipidemia is characterized by a dense $\beta$-lipoprotein band, no pre- $\beta$-lipoprotein band being present on the elec- 
tropheretograms; the glycolysis is enhanced postprandially, which leads to an increased lactate production and an increased liponeogenesis [4].

Although enhanced lipid production in the liver probably plays a causative role in the pathogenesis of GSD hyperlipidemia, it may not be the only factor. A pathologically low triglyceride clearance rate might also be an important factor. By measuring the triglyceride elimination rate and the serum postheparin lipoprotein lipase activity, we tried to gain more insight into the apparently complex causes of the hyperlipidemia.

\section{Materials and Methods}

The study comprised seven patients with a glucose 6phosphatase deficiency, seven patients with a debranching enzyme deficiency, and six patients with a deficiency of the phosphorylase system. Enzymatic studies had confirmed the diagnosis in all patients (Tables I-III). Ten patients without hyperlipidemia in whom an intravenous fat tolerance test had been performed served as control subjects (Table IV). They all had a normal nutritional status. Informed consent was obtained in each case.

An intravenous fat tolerance test was performed in all GSD patients and control subjects. Heparin-released plasma lipoprotein lipase (LPL) activity was measured in most GSD patients and in some control subjects. Both tests were performed on consecutive days. The patients and the control subjects did not fast before the tests in order to prevent hypoglycemia in the patients. The meals during the 12-hr period before each test did not contain fat. The last meal was always given $2 \mathrm{hr}$ before the test. The diet in the 2 weeks preceding the tests contained about $25 \%$ of total calories at fat, mainly polyunsaturated, for all patients.

The intravenous fat tolexance test [2] was carried out according to the method of Carlson and Rössner [3]. For all tests, a 20\% Intralipid emulsion [15] was administered intravenously in a dose of $0.1 \mathrm{~g} / \mathrm{kg}$ body wt. Capillary blood samples were collected every 5 min. The Intralipid concentration was determined by nephelometry. For each disappearance curve a minimum of four consecutive points was used. The logarithms of the Intralipid concentrations were plotted against time. Straight lines were obtained from which the correlation coefficients were calculated.

The LPL activities were measured after the intravenous injection of $100 \mathrm{U}$ heparin $/ \mathrm{kg}$ body wt in 5- and 40-min blood samples in most GSD patients, but in 5min blood samples only in most control subjects. As we concur with Rössner et al. [13] that the 5-min postheparin LPL activity probably gives more information about fat elimination than the 40 -min value, we have chosen the 5-min value as representative of LPL activity. The LPL activity was determined by the method of Kelly [11] as modified by Jansen and Hülsmann [9]. The following minor modifications were introduced: the incubation mixture consisted of $1.1 \mathrm{ml}$ Intralipid emulsion containing approximately $3.5 \mu \mathrm{Ci}$ $\left({ }^{14} \mathrm{C}\right)$ trioleate, $3.0 \mathrm{ml}$ human plasma freed of $\beta$-lipoproteins as described by Jansen and Hülsmann [9], $6.0 \mathrm{ml}$ $10 \%$ solution of bovine albumin in $0.2 \mathrm{~m}$ Tris buffer $\mathrm{pH} 8.5$, and $1.9 \mathrm{ml} 0.2$ Tris buffer, $\mathrm{pH} 8.5$. This mixture was kept at $37^{\circ}$ for $40 \mathrm{~min}$. After this pretreatment, $0.8 \mathrm{ml}$ incubation medium was mixed with 0.2 $\mathrm{ml}$ plasma to be investigated. The incubation time was $35 \mathrm{~min}$.

\section{Results}

\section{Intralipid Elimination Constant in Patients and Con- trol Subjects}

The Intralipid elimination constants of the patients with a glucose 6-phosphatase deficiency and of the patients with a debranching enzyme deficiency were significantly lower than those of the control patients $(P<0.05)$. For the patients with a deficiency of the phosphorylase system, the difference was not significant (Tables I-V).

\section{Heparin-released LPL Activity in Patients and Con- trol Subjects}

The heparin-released LPL activity was higher in the 5 -min sample than in the 40 -min sample in the majority of GSD patients. Three out of six glucose 6-phosphatase-deficient patients, and one out of four debranching enzyme-deficient patients, however, showed 5 -min activities lower than the 40-min activities. Most patients with a glucose 6-phosphatase deficiency showed lower 5-min LPL activities as compared with the control subjects, the difference between both groups being significant $(P<0.05)$. Some patients with a deficiency of debranching enzyme or a deficiency of the phosphorylase system showed decreased LPL activities as well, but the LPL activities of the latter two groups as a whole did not differ significantly from the LPL activities of the control subjects (Tables $\mathrm{I}-\mathrm{V})$. 
Table I. Data for seven patients with a glucose 6 -phosphatase deficiency ${ }^{1}$

\begin{tabular}{|c|c|c|c|c|c|c|c|c|c|c|}
\hline & \multirow[t]{2}{*}{ Case } & \multirow[t]{2}{*}{ Sex } & \multirow[t]{2}{*}{ Age, yr } & \multirow{2}{*}{$\begin{array}{l}\text { Cholesterol, } \\
\text { mmol/liter }\end{array}$} & \multirow{2}{*}{$\begin{array}{l}\text { Triglycerides, } \\
\text { mmol/liter }\end{array}$} & \multirow{2}{*}{$\begin{array}{l}\mathrm{K}_{2,}, \% / \\
\mathrm{min}^{2}\end{array}$} & \multirow[t]{2}{*}{$\mathbf{r}$} & \multicolumn{2}{|c|}{$\begin{array}{l}\text { Postheparin LPL activity, } \\
\mu \mathrm{Eq} \text { FA/liter/min }\end{array}$} & \multirow{2}{*}{$\begin{array}{l}\text { Glucose 6-phosphatase } \\
\text { in liver, nmoles } \\
\mathrm{P}_{i} / \mathrm{min} / \mathrm{mg} \text { protein }\end{array}$} \\
\hline & & & & & & & & $5 \min$ & $40 \mathrm{~min}$ & \\
\hline & 1. $C C$ & $\mathrm{~F}$ & 4.2 & 4.87 & 3.12 & 2.46 & 0.9936 & 13.0 & 5.6 & 0.0 \\
\hline & 2. $S S$ & M & 3.5 & 3.53 & 1.75 & 5.20 & 0.9947 & 36.7 & 49.1 & 1.0 \\
\hline & 3. $A R$ & $F$ & 2.9 & 5.78 & 8.55 & 3.00 & 0.9990 & 35.8 & 24.5 & 0.9 \\
\hline & 4. $A W$ & $\mathrm{~F}$ & 29.2 & 9.02 & 13.00 & 6.22 & 0.9973 & 24.0 & 28.1 & 0.0 \\
\hline & 5. $D S$ & M & 1.9 & 3.86 & 0.79 & 4.90 & 0.9933 & 30.8 & 38.8 & 1.7 \\
\hline & 6. $M B$ & $\mathrm{~F}$ & 3.2 & 3.35 & 2.47 & 9.00 & 0.9955 & 83.1 & & 5.1 \\
\hline & 7. $R S$ & $\mathrm{M}$ & 3.0 & 6.30 & 2.56 & 9.79 & 0.9950 & 57.3 & 19.3 & 1.8 \\
\hline \multicolumn{4}{|c|}{$\mathrm{n}$} & 7 & 7 & \multicolumn{2}{|c|}{7} & 7 & & $6^{3}$ \\
\hline $\mathrm{m}$ & & & & 5.24 & 4.60 & \multicolumn{2}{|c|}{5.79} & 40.2 & & \\
\hline$\sigma$ & & & & 2.29 & 4.46 & \multicolumn{2}{|c|}{2.78} & 23.0 & & \\
\hline
\end{tabular}

I F : female; M: male; LPL; lipoprotein lipase: FA : fatty acid.

2 Intralipid elimination constant [3].

${ }^{3}$ Normal range 24.0-93.0.

Table II. Data for seven patients with a debranching enzyme deficiency ${ }^{1}$

\begin{tabular}{|c|c|c|c|c|c|c|c|c|c|c|}
\hline \multirow[t]{2}{*}{ Case } & \multirow[t]{2}{*}{ Sex } & \multirow[t]{2}{*}{ Age, yr } & \multirow[t]{2}{*}{$\begin{array}{l}\text { Cholesterol, } \\
\mathrm{mmol} / \text { liter }\end{array}$} & \multirow[t]{2}{*}{$\begin{array}{l}\text { Triglycerides, } \\
\text { mmol/liter }\end{array}$} & \multirow[t]{2}{*}{$\begin{array}{c}\mathrm{K}_{2}, \% / \\
\min \end{array}$} & \multirow[t]{2}{*}{$\mathrm{r}$} & \multicolumn{2}{|c|}{$\begin{array}{l}\text { Postheparin LPL activ- } \\
\text { ity, } \mu \mathrm{Eq} \mathrm{FA} / \mathrm{liter} / \mathrm{min}\end{array}$} & \multicolumn{2}{|c|}{$\begin{array}{l}\text { Debranching enzyme, nmol } \\
\text { glucose produced from limit } \\
\text { dextrin } / \mathrm{min} / \mathrm{mg} \text { protein }\end{array}$} \\
\hline & & & & & & & $5 \min$ & $40 \mathrm{~min}$ & Leucocytes & Liver \\
\hline 1. $P L$ & $F$ & 15.2 & 6.75 & 2.00 & 4.30 & 0.9897 & 98.0 & 68.2 & 0.00 & \\
\hline 2. $D L$ & $\mathrm{~F}$ & 14.0 & 5.50 & 2.27 & 3.75 & 0.9974 & 60.9 & 41.9 & 0.00 & \\
\hline 3. $A D$ & $\mathrm{~F}$ & 11.9 & & & 7.05 & 0.9855 & 51.4 & & 0.00 & 0.00 \\
\hline 4. $J K$ & $\mathbf{F}$ & 7.4 & 3.73 & 0.95 & 5.86 & 0.9050 & & & 0.09 & 0.13 \\
\hline 5. $J B$ & $\mathrm{~F}$ & 5.8 & 4.04 & 2.90 & 3.98 & 0.9929 & 38.2 & & 0.00 & \\
\hline 6. $J Z$ & F & 12.0 & 6.88 & 4.09 & 6.36 & 0.9760 & 22.6 & 37.7 & 0.00 & 0.20 \\
\hline 7. $J K$ & $\mathrm{M}$ & 1.2 & 6.60 & 5.43 & 2.58 & 0.9906 & 26.4 & 18.0 & $0.20^{2}$ & $0.65^{2}$ \\
\hline Normal range & & & & & & & & & $0.33-1.80$ & $0.5-2.3$ \\
\hline $\mathrm{n}$ & & & 6 & 6 & 7 & & 6 & & 14 & 6 \\
\hline $\mathrm{m}$ & & & 5.58 & 2.94 & & .84 & 49.6 & & & \\
\hline$\sigma$ & & & 1.40 & 1.60 & & .61 & 27.7 & & & \\
\hline
\end{tabular}

${ }^{1} \mathrm{~F}$ : female; $\mathrm{M}$ : male; LPL: lipoprotein Iipase; FA: fatty acid.

2 The assay was modified and performed at a higher concentration of limit dextrin (normal range for leucocytes $2.07-5.04$ ( $\mathrm{n}=8$ ), for liver 2.13-9.09 $(\mathrm{n}=3)$.

\section{Levels of Triglyceride and Cholesterol in Blood in Patients and Control Subjects}

The triglyceride levels were significantly higher $(P$ $<0.05)$ in the three patient groups as compared with the control subjects. The cholesterol values were significantly increased in the patients with a debranching enzyme deficiency as compared with the control subjects (Tables I-V).

Correlations of Intralipid Elimination Constants, LPL Activities, and Levels of Triglyceride in Plasma of GSD Patients

The Intralipid elimination constants and the LPL activities 5 min after heparin injection showed a sig- nificant positive correlation $(\mathrm{r}=0.55, P<0.05$, Fig. 1). The Intralipid elimination constants and the plasma triglycerides, on the one hand (Fig. 2), and the LPL activities 5 min after heparin injection and the plasma triglycerides, on the other hand (Fig. 3), were not significantly correlated.

\section{Discussion}

Much work has been done to find the cause of the deficient LPL activity in disturbances of the triglyceride elimination system. The synthesis of LPL activity in adipose tissue taken from rats appears to be under hormonal control. Insulin has a positive effect, whereas catecholamines, glucagon, growth-stimulating 
Table III. Data for six patients with a deficiency of phosphorylase system ${ }^{1}$

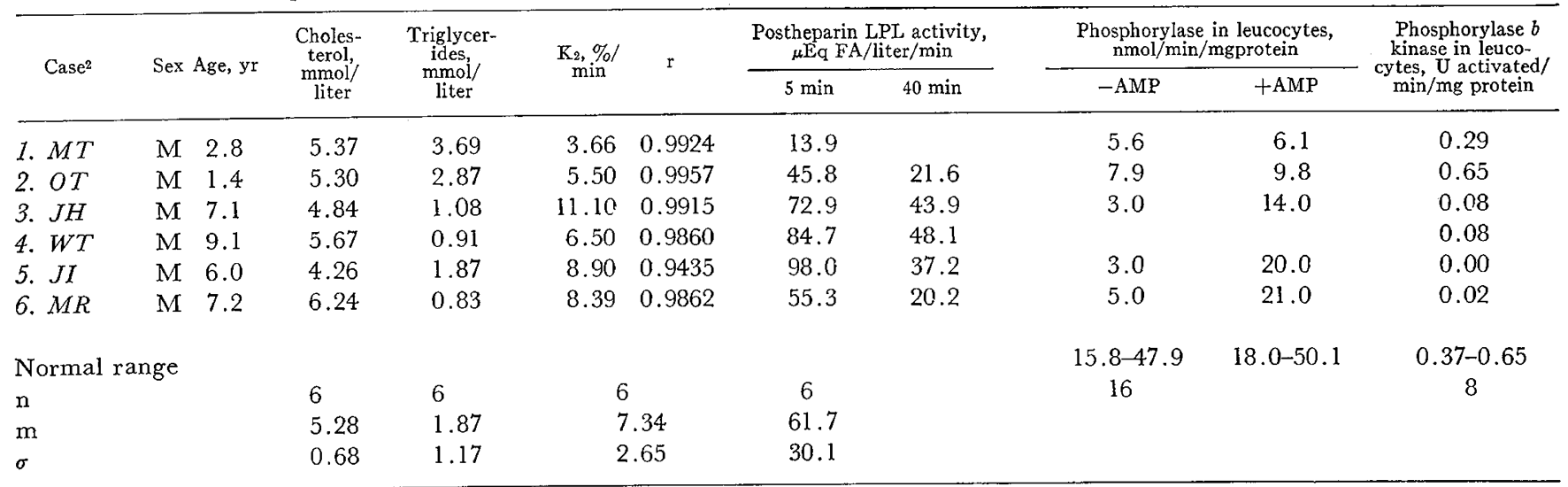

${ }^{1} \mathrm{M}$ : male; LPL: lipoprotein lipase; FA: fatty acid.

2 Patients 1 and 2 (brothers) are phosphorylase deficient; phosphorylase activity in the liver 0.0 and $0.0 \mathrm{nmoles} / \mathrm{min} / \mathrm{mg} \mathrm{protein}, \mathrm{respec}$ tively; patients 3-6 are phosphorylase $b$ kinase deficient; liver biopsy, performed in one patient (patient 4 ), confirmed the diagnosis.

Table IV. Data for 10 control children ${ }^{1}$

\begin{tabular}{|c|c|c|c|c|c|c|c|c|}
\hline \multirow{2}{*}{ Case } & \multirow{2}{*}{ Sex } & \multirow{2}{*}{ Age, yr } & \multirow{2}{*}{$\begin{array}{l}\text { Cholesterol, } \\
\mathrm{mmol} / \text { liter }\end{array}$} & \multirow{2}{*}{$\begin{array}{l}\text { Triglycerides, } \\
\text { mmol/liter }\end{array}$} & \multirow{2}{*}{$\underset{\min }{\mathrm{K}_{2}, \% /}$} & \multirow{2}{*}{$\mathrm{r}$} & \multicolumn{2}{|c|}{$\begin{array}{c}\text { Postheparin LPL activity, } \mu \mathrm{ec} \\
\mathrm{FA} / \mathrm{liter} / \mathrm{min}\end{array}$} \\
\hline & & & & & & & $5 \min$ & $40 \mathrm{~min}$ \\
\hline 1. $S E$ & $\mathrm{M}$ & 3.1 & 4.57 & 0.45 & 11.59 & 0.9894 & & \\
\hline 2. $K J$ & $\mathrm{~F}$ & 1.5 & 4.38 & 0.52 & 8.01 & 0.9958 & 72.4 & 67.4 \\
\hline 3. $F J$ & $\mathrm{~F}$ & 8.0 & 5.10 & 0.63 & 7.83 & 0.9791 & 102.7 & \\
\hline 4. $A D$ & $\mathrm{~F}$ & 4.2 & 4.60 & 0.93 & 5.70 & 0.9900 & & \\
\hline 5. $P C$ & $\mathrm{~F}$ & 7.8 & 5.01 & 0.70 & 7.06 & 0.9981 & 42.5 & \\
\hline 6. $O M$ & $\mathrm{M}$ & 4.2 & 4.35 & 0.68 & 8.66 & 0.9990 & & \\
\hline 7. $V C$ & $\mathrm{~F}$ & 12.3 & 3.50 & 0.86 & 8.86 & 0.9896 & & \\
\hline 8. VS & $\mathrm{F}$ & 8.1 & 4.23 & 0.60 & 7.11 & 0.9966 & & \\
\hline 9. $O C$ & $\mathrm{M}$ & 2.2 & 5.20 & 0.80 & 10.10 & 0.9820 & 113.7 & \\
\hline 10. $M R$ & $\mathrm{M}$ & 9.9 & & & 9.20 & 0.9970 & & \\
\hline & & & 9 & 9 & 10 & & 4 & \\
\hline & & & 4.54 & 0.68 & & 3.39 & 82.8 & \\
\hline & & & 0.52 & 0.15 & & .66 & 32.4 & \\
\hline
\end{tabular}

${ }^{1} \mathrm{M}$ : male; F : female; LPL: lipoprotein lipase; FA: fatty acid.

hormone, and adrenocorticotropic hormone have been shown to have a negative effect on the LPL activity [10]. Further studies on the factors regulating LPL activity were described in 1966 by Salamon and Robinson [14], who incubated intact epidymal fat bodies taken from rats that had been starved for $48 \mathrm{hr}$ and in which the activity of LPL was low, in a medium designed to promote enzyme activity. They found that, as expected, the LPL activity increased to a level characteristic of the tissue of intact animals in the fed state. Glucose and insulin were important constituents of the incubation medium, insofar as the omission of either markedly reduced the increase in enzyme activity. Therefore, LPL synthesis in patients with a glucose 6-phosphatase deficiency may be impaired by the low levels of glucose and insulin in blood [6]. As for our patients with this enzyme defect, not only LPL activities, but also Intralipid clearance rates were significantly reduced as compared with the control patients. Our patients deficient in debranching enzyme or the phosphorylase system, however, in whom symptoms of hypoglycemia are mild and rare, showed LPL activities that did not differ significantly from those of the control patients. Nevertheless, the patients with a debranching enzyme deficiency showed Intralipid clearance rates significantly lower than the control subjects. We have no explanation for the discrepancy between the normal LPL activity and decreased fat elimination in debranching enzyme-deficient patients.

Thus, we may explain the hyperlipidemia of GSD 
Table $V$. Intravenous fat tolerance test (IVFTT) and 5-min postheparin lipoprotein lipase (LPL) in glycogen storage disease patients and control subjects

\begin{tabular}{|c|c|c|c|c|c|c|c|}
\hline \multicolumn{4}{|c|}{ IVFTT $\mathrm{K}_{2}, \% / \mathrm{min}$} & \multicolumn{4}{|c|}{ 5-min postheparin LPL, $\mu \mathrm{eq} \mathrm{FA}$ / $/$ liter/min } \\
\hline $\begin{array}{c}\text { Glucose 6-phos- } \\
\text { phatase deficiency }\end{array}$ & $\begin{array}{l}\text { Debranching en- } \\
\text { zyme deficiency }\end{array}$ & $\begin{array}{l}\text { Phosphorylase } \\
\text { deficiency }\end{array}$ & Control subjects & $\begin{array}{l}\text { Glucose 6-phos- } \\
\text { phatase deficiency }\end{array}$ & $\begin{array}{l}\text { Debanching en- } \\
\text { zyme deficiency }\end{array}$ & $\begin{array}{l}\text { Phosphorylase } \\
\text { deficiency }\end{array}$ & Control subjects \\
\hline 2.46 & 4.30 & 3.66 & 11.59 & 13.0 & 98.0 & 13.9 & \\
\hline 5.20 & 3.75 & 5.50 & 8.01 & 36.7 & 60.9 & 45.8 & 72.4 \\
\hline 3.00 & 7.05 & 11.10 & 7.83 & 35.8 & 51.4 & 72.9 & 102.7 \\
\hline 6.22 & 5.86 & 6.50 & 5.70 & 24.0 & & 84.7 & \\
\hline 4.90 & 3.98 & 8.90 & 7.06 & 30.8 & 38.2 & 98.0 & 42.5 \\
\hline 9.00 & 6.36 & 8.39 & 8.66 & 83.1 & 22.6 & 55.3 & \\
\hline 9.79 & 2.58 & & 8.66 & 57.3 & 26.4 & & \\
\hline & & & $\begin{array}{r}7.11 \\
10.10\end{array}$ & & & & \\
\hline & & & $\begin{array}{r}10.10 \\
9.20\end{array}$ & & & & 113.7 \\
\hline 7 & 7 & 6 & 10 & 7 & 6 & 6 & 4 \\
\hline 5.79 & 4.84 & 7.34 & 8.39 & 40.2 & 49.6 & 61.7 & 82.8 \\
\hline 2.78 & 1.61 & 2.65 & 1.66 & 23.0 & 27.7 & 30.1 & 32.4 \\
\hline
\end{tabular}

1 FA: fatty acid.

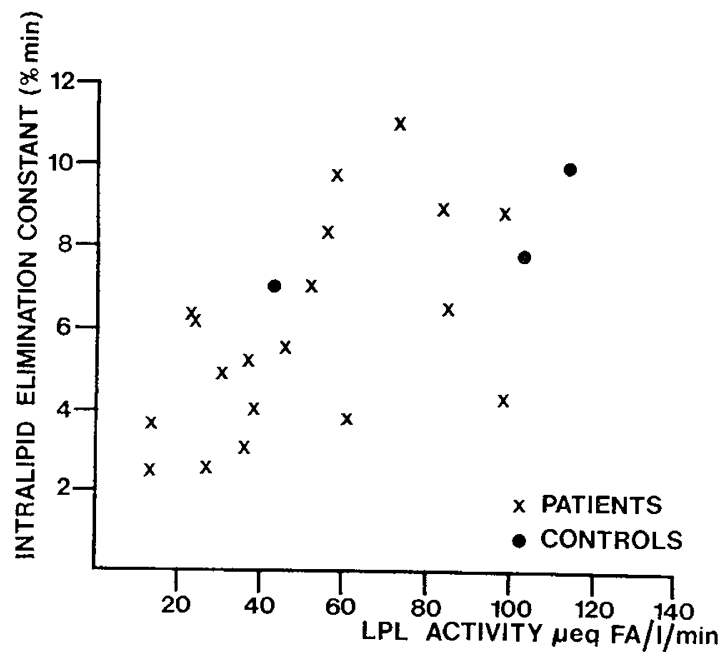

Fig. 1. Relation between lipoprotein lipase $(L P L)$ activities measured $5 \mathrm{~min}$ after the intravenous injection of $100 \mathrm{U}$ heparin $/ \mathrm{kg}$ body wt and Intralipid elimination constants of patients with glycogen storage disease and control subjects. $F A$ : fatty acid.

patients as follows. The hypertriglyceridemia of patients with a glucose 6-phosphatase deficiency is due to a combination of a decreased triglyceride elimination rate and increased endogenous liponeogenesis [7, 12], the former factor being the more important one. We did, indeed, observe that a high fat diet worsens the hypertriglyceridemia, which thus seems to be fat-induced (data not shown). The hyperlipidemia of patients with a deficiency of debranching enzyme or the phosphorylase system, however, is mainly caused by carbohydrate-induced liponeogenesis [4], as impaired fat elimination probably plays a significant role in debranching enzyme deficiency only. (Discrepant results of fat elimination tests in debranching enzyme deficients do not permit a firm conclusion.) The dietary implications should be that for children deficient

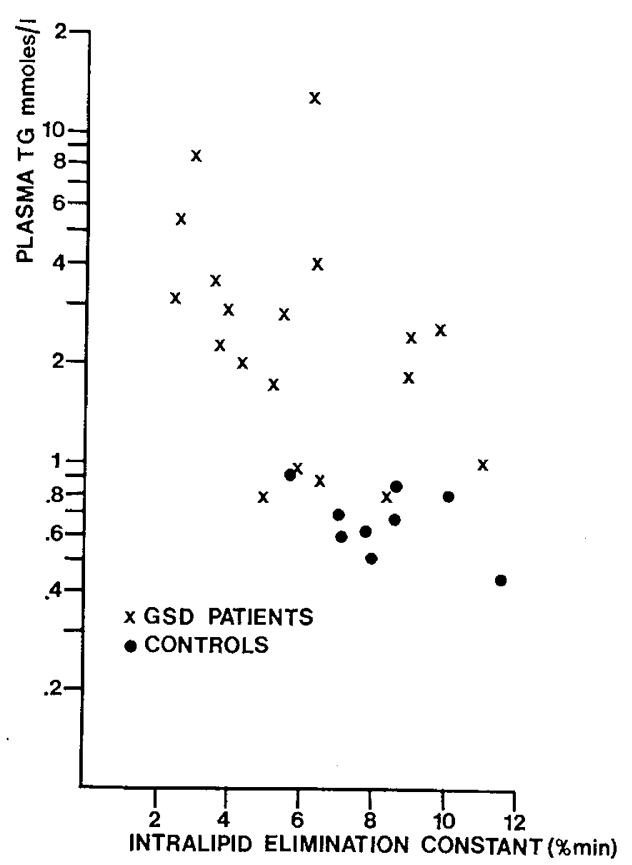

Fig. 2. Relation between Intralipid elimination constants and levels of triglyceride (TG) in plasma (log values) of patients with glycogen storage disease $(G S D)$ and control subjects. 


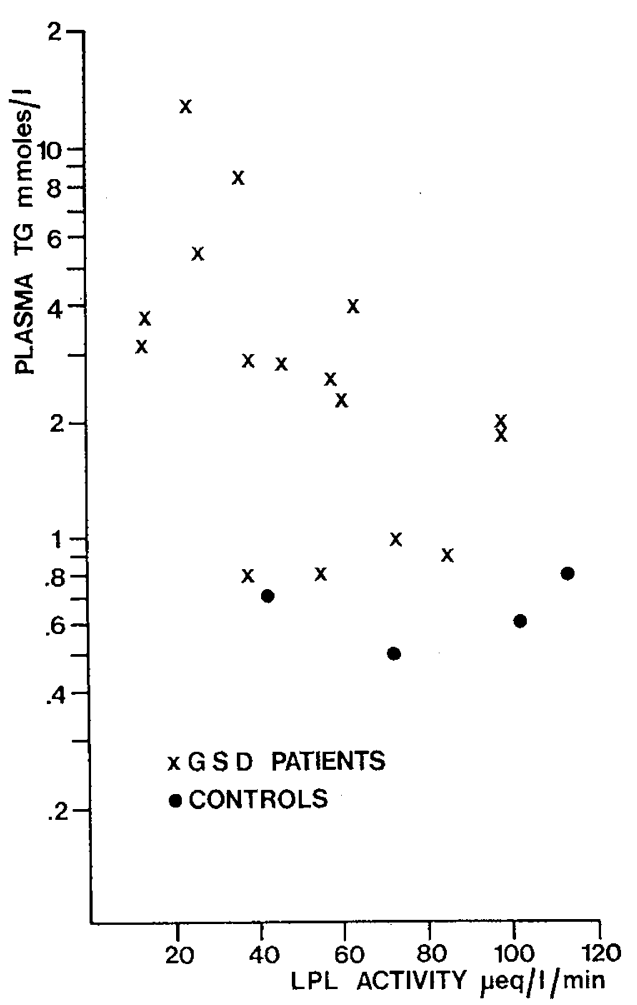

Fig. 3. Relation between lipoprotein lipase $(L P L)$ activities measured $5 \mathrm{~min}$ after the intravenous injection of $100 \mathrm{U}$ heparin $/ \mathrm{kg}$ body wt and levels of triglyceride (TG) in plasma (log values) of patients with glycogen storage disease $(G S D)$ and control subjects.

in glucose 6-phosphatase, a low fat, high carbohydrate diet is indicated, whereas for children with phosphorylase deficiency and possibly also those with a debranching enzyme deficiency, carbohydrate rather than fat restriction is indicated.

\section{Summary}

The hyperlipidemia of 20 patients with GSD was studied by the intravenous Intralipid tolerance test and the determination of the plasma postheparin lipoprotein lipase activity. Patients with a glucose 6-phosphatase deficiency were characterized by abnormally low results for both tests as compared with control children. Patients with a deficiency of debranching enzyme showed a decreased Intralipid elimination constant, whereas the LPL activities did not significantly differ from control values. Patients with a deficiency of the phosphorylase system showed normal results for both tests.
A positive correlation was found between the Intralipid elimination constant and the postheparin LPL activity in the patients.

\section{References and Notes}

1. BoBERG, J.: Heparin released blood plasma lipoprotein lipase activity in patients with hyperlipoproteinemia. Acta Med. Scand., 191: 97 (1972).

2. Boberc, J., Carlson, L. A., ANd Hallberg, D.: Application of a new intravenous fat tolerance test in the study of hypertriglyceridemia in man. J. Atheroscler. Res., 9: 159 (1969).

3. CARLson, L. A., AND Rössner, S.: A methodological study of an intravenous fat tolerance test with intralipid emulsion. Scand. J. Clin. Lab. Invest., 29: 271 (1972).

4. Fernandes, J., and Pikaar, N. A.: Hyperlipemia in children with liver glycogen disease. Amer. J. Clin. Nutr., 22: '617 (1969).

5. Howell, R. R., Ashton, D. N., and Wijgaarden, J. B.: Glucose-6-phosphatase deficiency glycogen storage disease: Studies on the interrelationships of carbohydrate, lipid, and purine abnormalities. Pediatrics, 29: 553 (1962).

6. Hug, G., and Schubert, W. K.: Serum insulin in type I glycogenosis: Effect of galactose or fructose administration. Diabetes, 16: 791 (1967).

7. Hülsmann, W. C., Eujkenboom, W. H. M., Koster, J. F., AND Fernandes, J.: Glucose 6-phosphatase deficiency and hyperlipemia. Clin. Chim. Acta, 30: 775 (1970).

8. Jacovic, S., Khachadurian, A. K., and Hsia, D. Y. Y.: The hyperlipidemia in glycogen storage disease. J. Lab. Clin. Med., 68: 769 (1966).

9. Jansen, H., and Hülsmann, W. C.: Long-chain acyl-CoA hydrolase activity in serum: Identity with clearing factor lipase. Biochim. Biophys. Acta, 296: 24I (1973).

10. Jeanrenaud, B., Hepp, D.: Adipose Tissue Regulation and Metabolic Functions (Academic Press, New York, 1970).

11. KelLy, T. F.: Rapid assay of labelled free fatty acids in a mixture of labelled lipids. J. Lipid Res., 9: 799 (1968).

12. Pikaar, N. A., and Fernandes, J.: Palmitic acid as an index of carbohydrate induced lipogenesis (unpublished data).

13. Rössner, S., Larsson-Cohn, W., Carlson, L. A., and Boberg, $\mathrm{J} .:$ Effects of an oral contraceptive agent on plasma lipids, plasma lipoproteins, the intravenous fat tolerance and the post-heparin lipoprotein lipase activity. Acta Med. Scand., 190: 301 (1971).

14. Salamon, M. R., and Robinson, D. S.: Clearing factor lipase in adipose tissue: A medium in which the enzyme activity of tissue from starved rats increases in vitro. Biochem. J., 99: 640 (1966).

15. Batch 292174, Vitrum, Stockholm.

16. The technical assistance of Miss N. de Kort is gratefully acknowledged.

17. Requests for reprints should be addressed to: P. P. Forget, M.D., Sophia Childrens Hospital, Erasmus University, Rotterdam, The Netherlands.

18. Accepted for publication October 1, 1973. 